\title{
Analysis of Indoor Thermal Comfort of Room Space in the International Standard Hotel Building
}

\author{
Nasrullah Sahid \\ Postgraduate Students, Department of Architecture, \\ Faculty of Engineering, Hasanuddin University. Makassar 90245, Indonesia \\ Ramli Rahim \\ Building Science and Technology Laboratory, \\ Department of Architecture,Faculty of Engineering, Hasanuddin University \\ Baharuddin Hamzah \\ Building Science and Technology Laboratory, \\ Department of Architecture,Faculty of Engineering, Hasanuddin University \\ Rosady Mulyadi \\ Building Science and Technology Laboratory, \\ Department of Architecture,Faculty of Engineering, Hasanuddin University
}

\begin{abstract}
The objective of this study was to analyze the indoor thermal comfort of room space international standard hotel buildings. The sample of the study was guests staying at five international standard hotels. The total sample were 1,092 people from five international standard hotels then sampling through Slovin formula of $10 \%$ to determine the number of respondents as many as 92 respondents. Primary data was collected through survey and questionnaires. Data was analyzed with software regarding air temperature of international standard hotel rooms both indoor and outdoor has fulfilled the prerequisites of ASHRAE, Thermal Environmental Conditions for Human Occupancy (Standard 55-66).Indoor air temperature of the five hotels observed was between $28.85{ }^{\circ} \mathrm{C}$ to $29.54{ }^{\circ} \mathrm{C}$, with the air temperature approaching the comfort zone ranging from $20.5{ }^{\circ} \mathrm{C}$ to $27.1{ }^{\circ} \mathrm{C}$. The outdoor air temperature of international standard hotel room space observed is on average range between 28.42 ${ }^{\circ} \mathrm{C}$ to $40.52{ }^{\circ} \mathrm{C}$, with a standard deviation ranging from 0.01 to 0.44 . The maximum value is between $28.45{ }^{\circ} \mathrm{C}$ to $41.41{ }^{\circ} \mathrm{C}$ and a minimum value is $28.40{ }^{\circ} \mathrm{C}$ to $39.87{ }^{\circ} \mathrm{C}$. Solar radiation on international standard hotel building observed is in an average range between 32.79 watts $/ \mathrm{m}^{2}$ to 769.75 watts $/ \mathrm{m}^{2}$, with a standard deviation ranging from 0.95 to 285.43 watts / $\mathrm{m}^{2}$. The maximum value is between 36.37 to 918.97 watts / $\mathrm{m}^{2}$ and a minimum value is between 30.08 to 715.63 watts $/ \mathrm{m}^{2}$. Solar radiation has a major influence in changing the indoor thermal comfort temperature in hotel rooms.
\end{abstract}

Keywords: Indoor Thermal Comfort, Air Temperature, Air Velocity, Solar Radiation, International Standard Hotel

\section{INTRODUCTION}

International standard hotel buildings are commercial buildings that must be equipped with various operational facilities which guarantee indoor thermal comfort (Bohdanowicz \& Martinac, 2002). Thermal comfort according to the American Society of Heating, ASHRAE, Thermal Environmental Conditions for Human Occupancy (Standard 55-66) as "state of mind expressing satisfaction with the thermal environment" (ANSI/ASHRAE, 2017). Then it is defined by the International Standard Organization (ISO) in Standard 7730 (ISO, 2005). According to Gagge et al. (1967) feeling comfortable is difficult because it implements the 
entire environment including psychological and physiological aspects. In detail, Fanger (1970) explains that indoor thermal comfort is determined by several factor, include thermal environment, personal factors and other contributing factors.

There are many unsolved problems in indoor thermal comfort studies especially in the tropics for the international standard hotel buildings in Indonesia. The main problems are environmental factors include air temperature, air velocity and radiation (Fanger, 1970). The ASHRAE standard for human occupancy, explains the demand characteristics for healthy room in principle must be adjusted with the accepted or tolerated conditions of the air temperature environment. The goal of an acceptable feasibility standard is $80 \%$ for the average individual within the room according to the comfort thermal environment (Alfano et al., 2017). For international standards hotel, indoor thermal comfort standards in principle are mental and body conditions responding on their environment to know feelings of joy, comfort and desire to accept subjectively to describe and identify the indoor and radiation effects of air temperature settings which affect the room. At certain times, people in the hotel room feeling too cold to very hot, indoor thermal comfort felt like the cool air temperature, can receive coolness according to the wind velocity gusts, according to the solar radiation which very humid to very dry (Lala, 2017).

Comfort and discomfort index are important to be used as environmental parameters (Fabbri, 2015). The cause of discomfort is due to differences in air temperature indoor the room felt by the people in the room. Of course the difference of $5^{\circ} \mathrm{C}$ to $8^{\circ} \mathrm{C}$ from each treatment leads to subjective dissatisfaction. In general, the research evaluating indoor thermal comfort is carried out by direct survey of the observation location (Santoso, 2012), using thermal technology (Kyriaki et al., 2015). Intended to determine the accuracy of the temperature parameters observed (Ma et al., 2017). Everyone expect to live in a thermal environment where they feel comfortable. If the temperature is decreased combined with weather changes and radiation, people want to live in a warm environment, and if it is experienced, they want to live in a cold environment. Many studies have found a relationship between human indoor thermal comfort and physical environment variables which are human needs (Kim et al., 2013).

Buildings must be designed based on indoor thermal comfort, especially considering the influence of air temperature, wind velocity, solar radiation as a matter of significant influence on the thermal comfort of the room (O'hegarty et al., 2015). There are a number of hotel designs less attention to the standard dimensions of space that meet the criteria of comfort requirements for customers. Many of them sacrifice the comfort of inner space for customers by reducing the dimensions of the room to increase the number of rooms and for other space functions (Hendrarto et al., 2012). The circulation zone contained in buildings is used to connect spaces and activity to another. A circulation zone is designed to facilitate the mobility of users in order to be able to use and enjoy part or all of the building facilities (Pynkiawati et al., 2009). This is intended to have an indication of the relationship between temperature climates with the sleep quality of hotel room users (Rupp et al., 2015).

The hotel as a guest rest place is designed to have rooms with suitable thermal comfort with comfortable air temperatures during the day and at night. The air temperature the building should be maintained in accordance with air velocity, radiation intensity and humidity level with the aim of obtaining thermal comfort (Tharziansyah \& Rahman, 2008). Various air temperature differences effect on the various thermal effects air temperature, air velocity, and solar radiation which affect the condition of buildings (Gandhi et al., 2018). Thermal comfort standards such as ASHRAE standard 55 (ANSI/ASHRAE, 2013) have been widely used to design thermal comfort in various countries, including in determining the thermal comfort of 
international standard hotels. Thermal comfort standards are divided into 7 scales, namely: hot $(+3)$, warm $(+2)$, slightly warm $(+1)$, neutral $(0)$, slightly cold $(-1)$, cool $(-2)$ and cold $(-3)$ (Fanger, 1970; Hamzah et al., 2018).

For the Government of Indonesia to provide comfort thermal guidance for buildings in general based on the Indonesian National Standard (SNI) 03-6572-2001 (BSN, 2001) where buildings must provide a thermal environment: 1) cold comfort: $20.5-22.8{ }^{\circ} \mathrm{C}(\mathrm{Te}) ; 2$ ) comfort: 22.8 $25.8^{\circ} \mathrm{C}(\mathrm{Te})$; and warm comfort: $25.8-27.1{ }^{\circ} \mathrm{C}(\mathrm{Te})$ (Hamzah et al., 2018). This guideline uses effective temperature (Te) which is defined as the stagnant and saturated atmosphere temperature, producing the same effect as the atmosphere in objective observations. Therefore, the combination effect of dry and humidity temperature is made (Auliciems \& Szokolay, 2007), so thermal and energy management needs to be used in a variety of thermal management systems (Zhang et al., 2018).

One important problem in achieving indoor thermal comfort in buildings is the influence of different type of building functioning. Depends on the activity occurs in the hotel (Alwetaishi, 2016). Efforts to reduce high air temperatures can be done by green area to soothing the thermal atmosphere of the environment around the hotel building (Kosonen et al., 2010). The international standard used to determine indoor thermal comfort prerequisites for room utilities must have a comfortable temperature at $23.3{ }^{\circ} \mathrm{C}$, so comfort quality is required according to the Percentage of Dissatisfaction Prediction index (PPD Index) (Jaffal et al., 2012). The number of star-rated hotels with international standards has sprung up in Indonesia affecting the thermal conditions of the air temperature in each room. Through observation, it was found a number of wasteful hotel rooms in the utilization of air conditioning (AC). To minimize energy use and realize indoor thermal comfort the room space of a hotel building, it is necessary to analyze indoor thermal comfort in the room. The objectives of this study are:

1. Reporting the indoor thermal environmental conditions the rooms in international standard hotel buildings.

2. Analyzing response of hotel guests staying toward the indoor thermal environment conditions in room space.

3. Finding operational temperatures in each hotel room based on the Indonesian climate.

\section{Research Samples and Respondents}

\section{RESEARCH METHODS}

This study was conducted at five hotels which were observed the room temperature conditions indoor hotel rooms based on indoor and outdoor temperatures. The observation treatment was conducted by assessing the temperature condition after all air condition (AC) is turned off. The treatment of the observed time range was determined based on the time of observation to measure air temperature and solar radiation by setting three times namely 9:00, 12:00. And 15:00. The research was conducted at international standard hotels by determining five hotels, namely: 1) Grand Clarion has 17 floors with 533 rooms; 2) Aryaduta has 10 floors with 224 rooms; 3) Sahid Jaya has 12 floors with 204 rooms; 4) Swiss-Belhotel has 22 floors with 296 rooms; and 5) Aston has 19 floors with 177 room spaces. More details are shown in the table below: 
Table 1.Number of Floors and Rooms in International Standard Hotel

\begin{tabular}{lccccc}
\hline \multirow{2}{*}{ Data } & \multicolumn{5}{c}{ Hotel } \\
\cline { 2 - 6 } & Grand Clarion & Aryaduta & $\begin{array}{c}\text { Sahid } \\
\text { Jaya }\end{array}$ & $\begin{array}{c}\text { Swiss- } \\
\text { Belhotel }\end{array}$ & Aston \\
\hline $\begin{array}{l}\text { Number of Hotel } \\
\text { Floor }\end{array}$ & 17 & 10 & 12 & 22 & 19 \\
Number of Rooms & 533 & 224 & 204 & 296 & 177 \\
\hline
\end{tabular}

Sampling of this study is guests staying at five international standard hotels before observations. As for the number of samples registered at the reception based on length of stay:

Table 2. Samples registered at the International Standard Hotels (April, 2018)

\begin{tabular}{|c|c|c|c|c|c|}
\hline \multirow{2}{*}{ Hotels } & \multicolumn{4}{|c|}{ Length of Stay } & \multirow{2}{*}{ Amount } \\
\hline & 1 Day & 2 - 3 days & 4 - 5 days & $>1$ week & \\
\hline Grand Clarion & 211 & 155 & 95 & 9 & 470 \\
\hline Aryaduta & 120 & 20 & 45 & 3 & 188 \\
\hline Sahid Jaya & 89 & 34 & 28 & 0 & 151 \\
\hline Swiss-Belhotel & 114 & 32 & 13 & 2 & 161 \\
\hline Aston & 82 & 24 & 16 & 0 & 122 \\
\hline Total Respondents & 616 & 265 & 197 & 14 & 1,092 \\
\hline
\end{tabular}

Total sample of 1,092 people from five international standard hotels is then carried out by the sampling through Slovin formula to determine the number of respondents. The Slovin formula uses a confidence level of 0.05 or $5 \%$ with the following formulations:

Information:

$$
\mathrm{n}=\frac{N}{1+N e^{2}}
$$

$\mathrm{n}=$ Number of Respondents

$\mathrm{N}=$ Sample Size

$\mathrm{e}=$ Level of Trust $(10 \%=0.10)$

So the number of respondents:

$$
\mathrm{n}=\frac{1.092}{1+(1.092)(0,10)^{2}}
$$

So the sample in this study was 92 respondents, distributed in each hotel using the formula below:

Distribution of Respondents $=\frac{\mathrm{N} \text { sample }}{\mathrm{N} \text { total }}$

More details about distribution results of respondents are shown in the table below: 


\section{Table 3. Distribution of Guest Respondents at International Standard Hotel}

\begin{tabular}{ccc}
\hline Hotels & Samples & Respondents \\
\hline Grand Clarion & 470 & 40 \\
Aryaduta & 188 & 16 \\
Sahid Jaya & 151 & 13 \\
Swiss-Belhotel & 161 & 13 \\
Aston & 122 & 10 \\
\hline Total Respondents & 1.092 & 92 \\
\hline
\end{tabular}

Based on the table above, shows the distribution of respondents were distributed questionnaires for surveys of room temperature during their stay, namely Grand Clarion Hotel as many as 40 respondents, Aryaduta Hotel 16 respondents, Sahid Jaya Hotel 13 respondents, Swiss-Belhotel 13 respondents and Aston Hotels there are 10 respondent.

\section{Research Instruments}

There are several instruments used to observe the indoor thermal comfort the rooms in the hotel building. A set of tools of HOBO Temp / Relative Humidity (RH) Indoor (UX100-011) which is equipped with several sensors and data loggers (Hobo-1) of four units placed in each room which are oriented north, south, east and west at the same time in one hotel building. HOBO Temp / Humidity Outdoor (MX 2300) is to measure air temperature and outdoor air relative humidity (Hobo-2). Instruments used to measure the average temperature of solar radiation (MRT) in the form of HOBO Solar Radiation Sensors (S-LIB-M003) and HOBO H21 USB Micro Station Data Logger (Hobo-3).

Figure 1. (a) HOBO-1 temp / Relative Humidity (RH) Indoor; (b) Hobo-2 temp / Relative Humidity Outdoor MX 2300; and (c) Solar Radiation / Micro Station Data Loggers

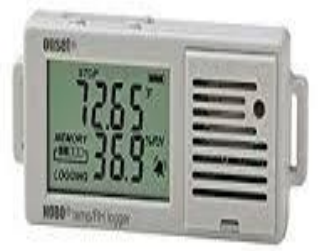

a. Hobo1

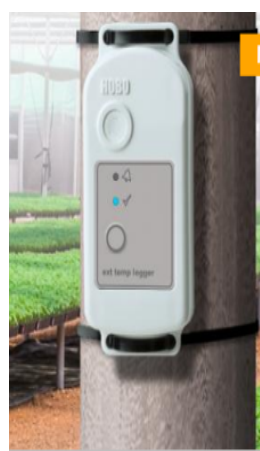

b. Hobo2

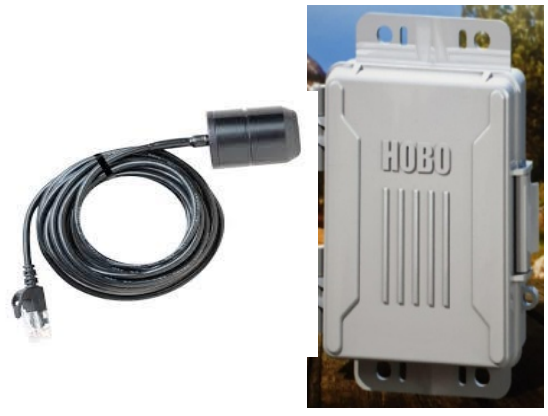

c. Hobo3

The specifications of the instruments used in data collection are shown in table 4 (Hamzah et al., 2018). 
Table 4. Specifications of the instruments used in Data Collection

\begin{tabular}{|c|c|c|c|c|}
\hline No. & Instrument Name & Range & Accuracy & Resolution \\
\hline \multirow[t]{3}{*}{1} & HOBOTemp/RHlogger (U & 11) & & \\
\hline & - Air Temperature & -20 to $+70^{\circ} \mathrm{C}$ & $\pm 0.21^{\circ} \mathrm{C}$ & $0.024^{\circ} \mathrm{C}$ \\
\hline & - $\quad$ Relative humidity & 5 to $95 \%$ & $\pm 2.5 \%$ & $0.05 \%$ \\
\hline \multirow[t]{3}{*}{2} & $\begin{array}{l}\text { HOBOTemp/RH/Light/ } \\
(\text { MX 2300) }\end{array}$ & & & \\
\hline & - Air Temperature & -20 to $+70^{\circ} \mathrm{C}$ & $\pm 0.21^{\circ} \mathrm{C}$ & $0.024^{\circ} \mathrm{C}$ \\
\hline & - $\quad$ Relative humidity & 5 to $95 \%$ & $\pm 2.5 \%$ & $0.05 \%$ \\
\hline \multirow[t]{2}{*}{3} & Solar Radiation/Data Logg & & & \\
\hline & -Radiant temperature & -40 to $+80^{\circ} \mathrm{C}$ & NA & $0.01^{\circ} \mathrm{C}$ \\
\hline
\end{tabular}

\section{Data Collection}

Primary data has been collected through survey methods and questionnaires. Data collection was obtained as follows:

1. An objective measurement survey was conducted to collect environmental data around hotel and thermal buildings. Data of indoor room space the hotel, surveyed for subjective measurements in measuring the indoor thermal comfort level of hotel guest respondents. The survey was conducted using questionnaire by asking questions, which captured Thermal Sensation Voice (TSV), Thermal Comfort Voice (TCV), thermal preferences and thermal receipts of respondents. In addition to air temperature, the questionnaire provided was intended to get respondents' responses to air velocity, preferences of air velocity and humidity indoor the hotel room. The TSV response was measured based on ASHRAE standard 55, which uses a seven-point scale to measure the respondent's thermal sensation.

2. Indoor thermal comfort can also be measured by asking for thermal preferences and recipients of occupants (in this case hotel guest respondent). Thermal preferences are related to the question of whether hotel guests prefer to be warmer or cooler or there are no changes. In addition, questions related to air velocity and humidity was also included in the questionnaire. At the top of the questionnaire, respondents wrote the name of the hotel, room number, respondent's name, gender, age, weather conditions and the position of the room occupied. Hotel guests fill out questionnaires for at least 25 to 30 minutes in each room the researcher will visit. To prevent mistakes in choosing relevant answers based on hotel guest preferences, an explanation of the indicators used in the questionnaire that have been carried out, for example, the difference between "Very cold", "cold", "neutral", warm "and" hot ". 
Table 5. Indoor Thermal Comfort Questionnaire (ANSI/ASHRAE, 2013; ANSI/ASHRAE, 2017).

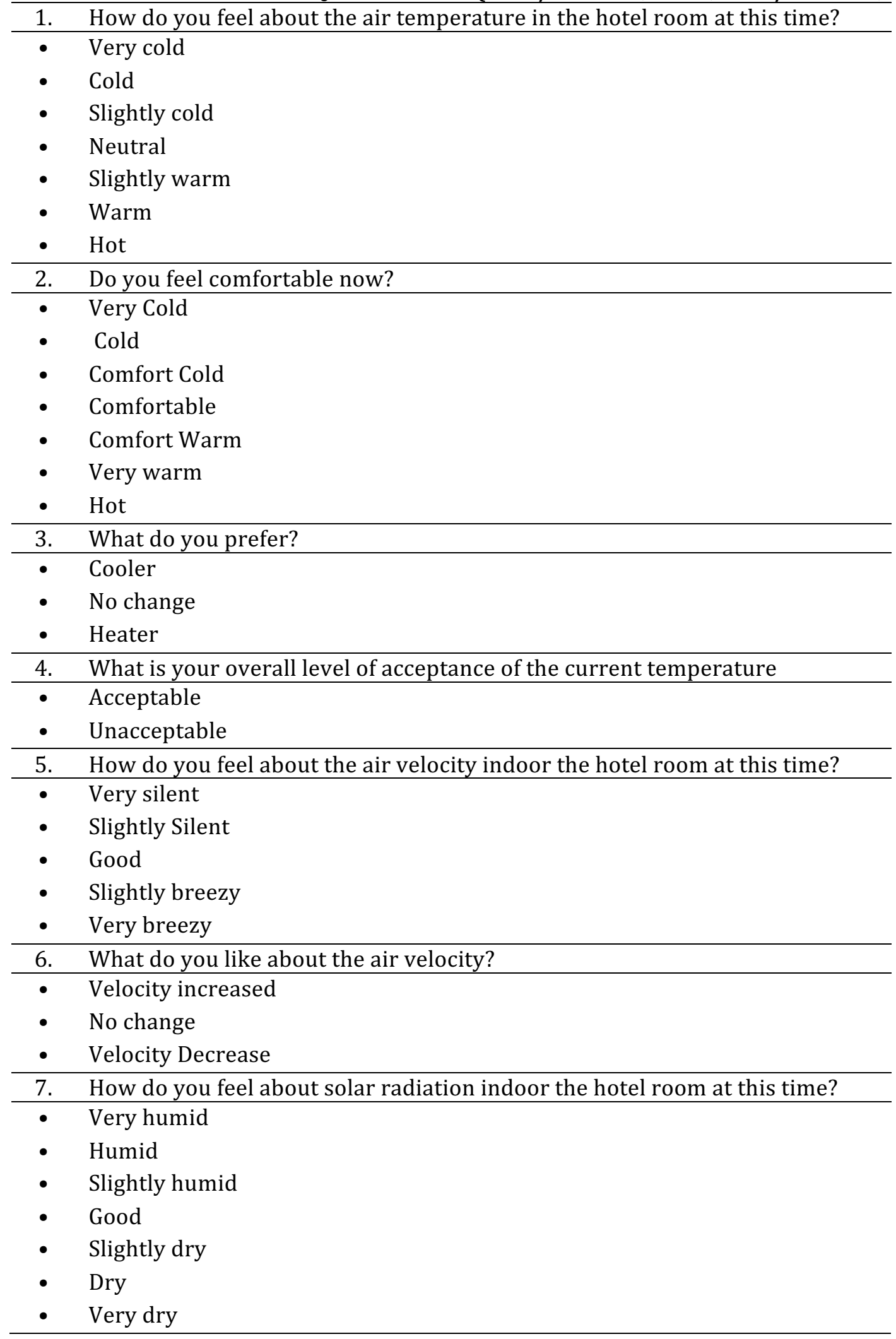

\section{Process and Data Analysis}

Data analysis was performed with MS Excel spreadsheet software and SPSS statistical package. Excel is used to calculate the average value of thermal environment variables and to produce a table showing the condition of a hotel room. For statistical analysis, SPSS version 23 with regression analysis was used. Regression analysis checks the correlation and linearity of data between TSV and operating temperature (To), TVC and operating temperature (To), and 
between PMV and operating temperature (To), TSV and TCV are collected from respondents' answers written in the questionnaire, while PMV is calculated based on ASHRAE standards using Excel software (ANSI/ASHRAE, 2013). PMV values are calculated by Excel software with sample calculations provided in the ASHRAE standard. According to Nicol (2004), the problem of using PMV in predicting indoor thermal comfort in hot climates in tropical countries is because the air temperature and air velocity exceed the limits that can be handled by PMV. Although the air temperature exceeds the PMV model limit, it can be used as an indicator to evaluate the indoor thermal comfort of buildings in the tropics. TSV responses are grouped according to ASHRAE scale, while TCVs are grouped using the Bedford scale.

To calculate PMV for each respondent, there are four appropriate environmental variables and two personal variables for each respondent. However, not all variables are collected due to limited equipment. MRT is only measured in the central point of the hotel room, while the air velocity value is measured at two points, namely A and B. To simplify the calculation process, the MRT score is applied to all points. Regarding air velocity, the arrangement is the air velocity score collected in a divided by points $C$ and $E$, while those collected at point $B$ are divided by point $\mathrm{D}$ and $\mathrm{F}$ respectively. By applying this arrangement, all respondents who are near the measurement point should have all six variables needed. This makes it possible to calculate PMV score based on four environmental variables and two personal. PMV for 92 respondents has been calculated.

The results of the study were analyzed based on statistical analysis using SPSS version 23 . The statistical analysis used was regression analysis, which was based on Pearson correlation. Acceptance of linear regression analysis is determined by two criteria: regression linearity test (F-test) and the significance of the equation coefficient (t-count). This equation is statistical linear if the absolute value of F-count $>$ F-table and significant value < probability (0.05). Table $\mathrm{F}$ for the case is 3,844 . The equation coefficient is significant if the absolute value of $t$-count $>t-$ table and the significance of the value <half of the probability $(0.025$ for two tail). The T-table for the infinity of degrees of freedom is 1960. The data used for statistical analysis has been verified by checking its normality and reliability.

\section{Participants'}

\section{RESULTS}

The Participants' identity in form of gender, age, education level and work period, is presented to find out the number of frequencies and the percentage of respondents who are representative in giving responses.

\section{Hotel Location and Sketch}

Location of the study was conducted in Indonesia with observations of international standard hotels in the city of Makassar. The following is shown in the lay out of five international standard hotels observed. Location of the measurement point is marked with a description of the rooms R1, R2, R3, and R4.

\section{Grand Clarion Hotel}

Grand Clarion Hotel is located at AP. Pettarani 03 Makassar street, established in 2006, the hotel has been used for 11 years with 17 floors which have 533 rooms providing 17 types of rooms which having Air Condition system based on indoor and outdoor temperatures. 


\section{Figure 2. Lay Out of Clarion Hotel Makassar}
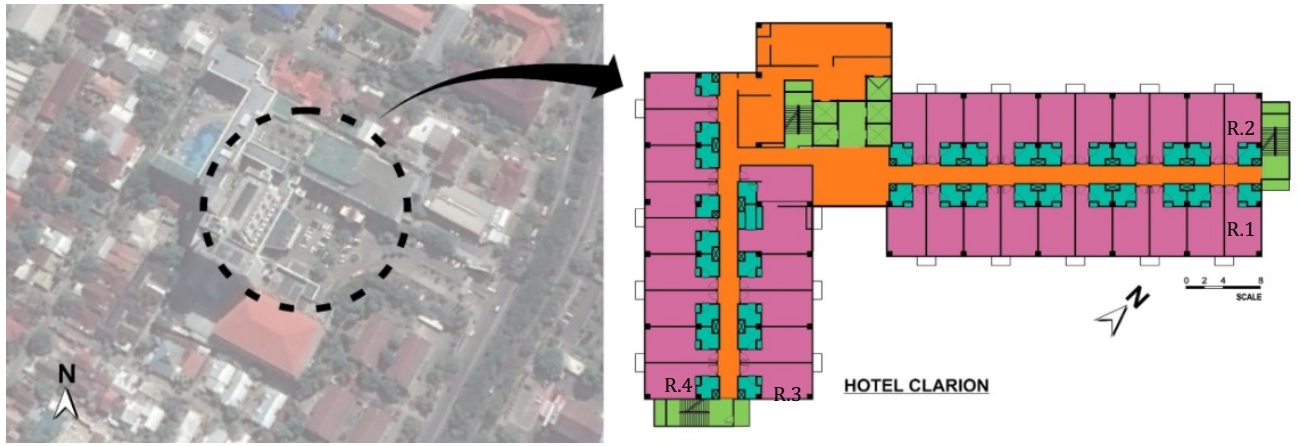

\section{Aryaduta Hotel}

Aryaduta hotel is located at Somba Opu 297 Makassar street, was established in 1996, the hotel has been used for 21 years with 10 floors that have 224 hotel rooms providing 13 types of rooms which having Air Condition systems based on indoor and outdoor temperatures.

Figure 3. Lay Out of Aryaduta Hotel Makassar.

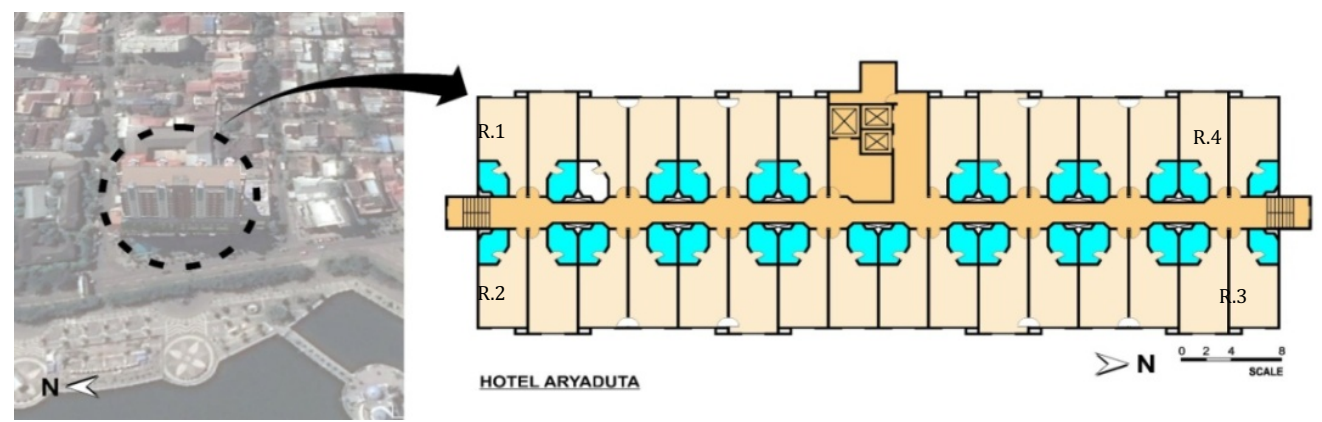

\section{Sahid Jaya Hotel}

Sahid Jaya Hotel is located at DR. Ratulangi 33 Makassar street, was established in 1996, the hotel has been used 21 years with 12 floors which has 204 hotel rooms providing 4 types of rooms, which having Air Condition system based on indoor and outdoor temperatures.

Figure 4. Lay Out of Sahid Jaya Hotel Makassar.

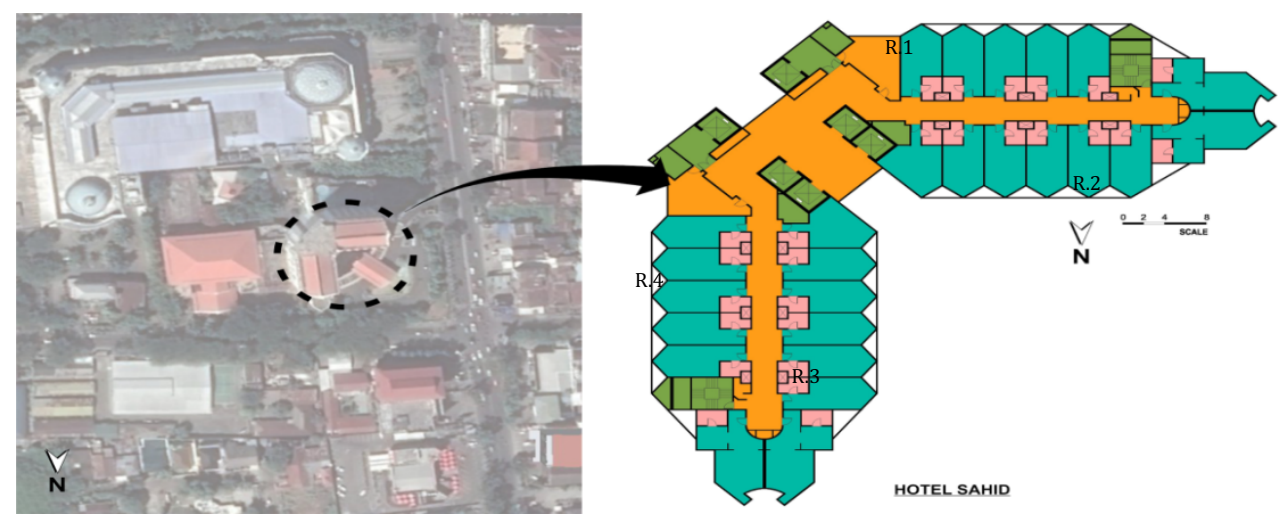

\section{Swiss-Belhotel}

Swiss-Belhotel, located at Ujung Pandang No 8 Makassar street, was established in 2016, the hotel has been used for 1 year with 22 floors that have 296 hotel rooms providing 6 types of rooms, namely having an Air Condition system based on indoor and outdoor temperatures. 


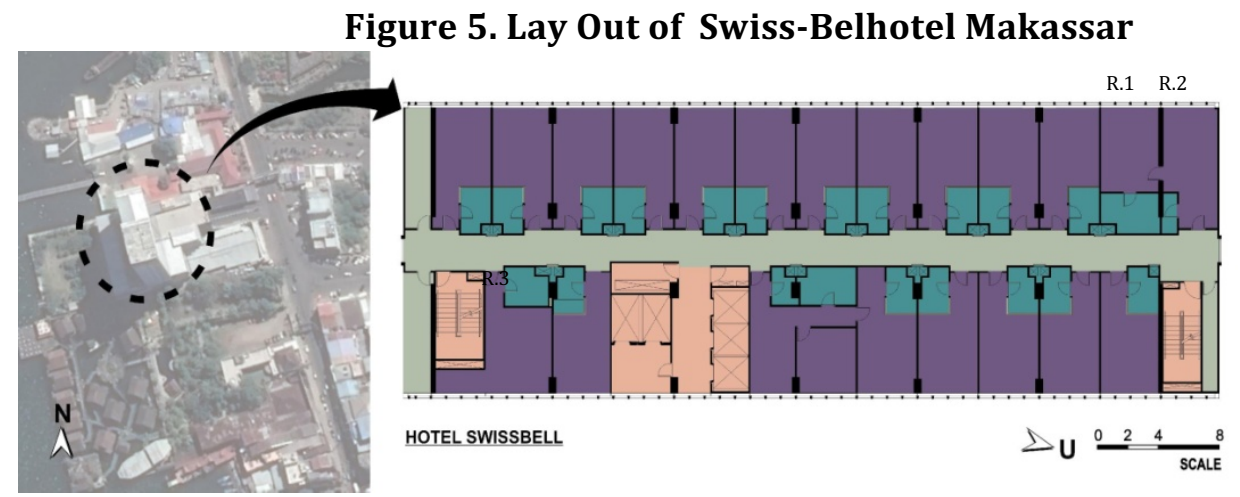

\section{Aston Hotel}

Aston Hotel, located at Sultan Hasanuddin 10 Makassar street, was established in 2010, the hotel has been used for 6 years with a number of 19 floors that have 177 hotel rooms providing 5 types of rooms, which having an Air Condition system based on indoor and outdoor temperatures.

Figure 6. Lay Out of AstonHotel Makassar.
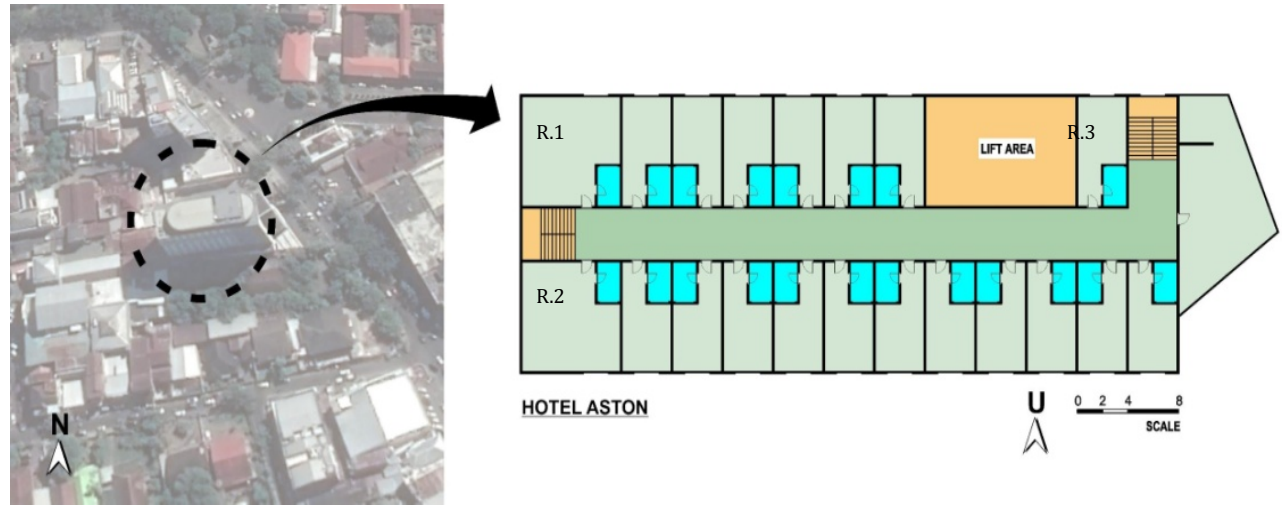

The survey was conducted on a clear day where the average outdoor temperature was $39.7^{\circ} \mathrm{C}$, with the minimum of $23.7{ }^{\circ} \mathrm{C}$ in the morning and a maximum of $33.4{ }^{\circ} \mathrm{C}$ during the day. The average relative humidity at that time was $69.2 \%$ with a minimum of $50.0 \%$ and a maximum of 85.8\%. This external thermal environment is collected from the Meteorological Station located at Sultan Hasanuddin International Airport (5 ${ }^{\circ} 4 \mathrm{~S}, 119^{\circ} 33^{\prime} \mathrm{E}, 17 \mathrm{~m}$ above sea level) about 20 $\mathrm{km}$ away from the city center.

\section{Indoor and Outdoor Room Temperature Conditions}

Room temperature conditions in international standard hotel rooms based on observation time for Grand Clarion hotels, Aryaduta and Sahid Jaya, there are four observations object rooms, while Swiss-Belhotel and Aston hotels, and have three observation objects. 
Table 6. Air Temperature Condition in International Standard Hotel Rooms

\begin{tabular}{lccccc}
\hline \multirow{2}{*}{ Hotel } & \multirow{2}{*}{$\begin{array}{c}\text { Time } \\
\text { (Hours) }\end{array}$} & \multicolumn{5}{c}{ Objective Observations of Room Air Temperature $\left({ }^{\circ} \mathrm{C}\right.$ ) } \\
\cline { 3 - 6 } & & R1 & R2 & R3 & R4 \\
\hline \multirow{3}{*}{ Grand Clarion Hotel } & $09: 00$ & 26.42 & 25.31 & 26.74 & 27.54 \\
& $12: 00$ & 30.26 & 30.73 & 30.69 & 30.62 \\
& $15: 00$ & 31.39 & 30.99 & 31.57 & 31.26 \\
\hline \multirow{3}{*}{ Aryaduta Hotel } & $09: 00$ & 29.18 & 29.81 & 28.78 & 27.75 \\
& $12: 00$ & 31.18 & 29.58 & 29.05 & 29.20 \\
& $15: 00$ & 31.71 & 29.53 & 29.03 & 29.70 \\
\hline \multirow{3}{*}{ Sahid Jaya Hotel } & $09: 00$ & 27,75 & 31,51 & 27,48 & 29,07 \\
& $12: 00$ & 27,93 & 30,66 & 28,34 & 28,11 \\
& $15: 00$ & 27,90 & 31,04 & 28,38 & 28,08 \\
\hline \multirow{3}{*}{ Swissbell Hotel } & $09: 00$ & 29.83 & 35.23 & 35.23 & - \\
& $12: 00$ & 29.58 & 34.20 & 34.20 & - \\
\hline \multirow{3}{*}{ Aston Hotel } & $15: 00$ & 29.71 & 32.53 & 32.53 & - \\
& $09: 00$ & 27.82 & 25.31 & 29.50 & - \\
& $12: 00$ & 28.33 & 30.73 & 30.88 & - \\
\hline
\end{tabular}

Room temperature in the Grand Clarion hotel room at 09:00 on four objectives observation in the range of $25.31{ }^{\circ} \mathrm{C}$ to $27.54{ }^{\circ} \mathrm{C}$, increased at $12: 00$ ranging from $30.26^{\circ} \mathrm{C}$ to $30.73{ }^{\circ} \mathrm{C}$, and by late afternoon at $15: 00$ still increasing with temperature ranging from $30.99{ }^{\circ} \mathrm{C}$ to $31.57{ }^{\circ} \mathrm{C}$. Furthermore, Aryaduta hotel room at 09.00 on the four observation objectives is in the range of $27.75{ }^{\circ} \mathrm{C}$ to $29.81{ }^{\circ} \mathrm{C}$, increased at 12.00 to $29.05{ }^{\circ} \mathrm{C}$ to $31.18{ }^{\circ} \mathrm{C}$, and by late afternoon at $15: 00$ still increasing with temperatures ranging from $29.03^{\circ} \mathrm{C}$ to $31.71{ }^{\circ} \mathrm{C}$. Similarly, the room air temperature in Sahid Jaya hotel rooms, at 09:00 on the four objectives observation in the range of $27.48{ }^{\circ} \mathrm{C}$ to $31.51{ }^{\circ} \mathrm{C}$, increased at 12 :00ranging from $27.93{ }^{\circ} \mathrm{C}$ to $30.66{ }^{\circ} \mathrm{C}$, and by late afternoon at $15: 00$ still increasing with temperatures ranging from $27.90{ }^{\circ} \mathrm{C}$ to $31.08{ }^{\circ} \mathrm{C}$. The three international standard hotels on four objectives observations show a comfort zone of $20.5^{\circ} \mathrm{C}-27.1^{\circ} \mathrm{C}$. More clearly the graph shows fluctuations in air temperature data as follows:

Figure 7. Data Fluctuations in Indoor Room Air Temperature for Grand Clarion, Aryaduta and Sahid Jaya

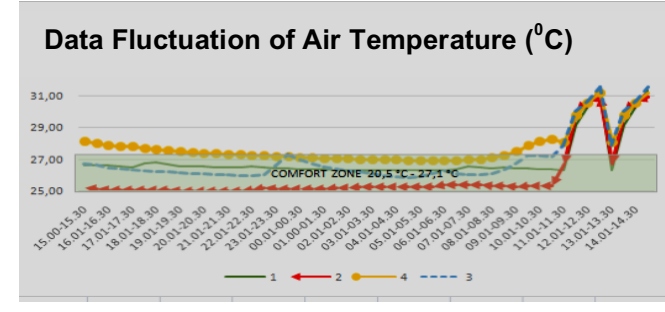

a. Grand Clarion Hotel

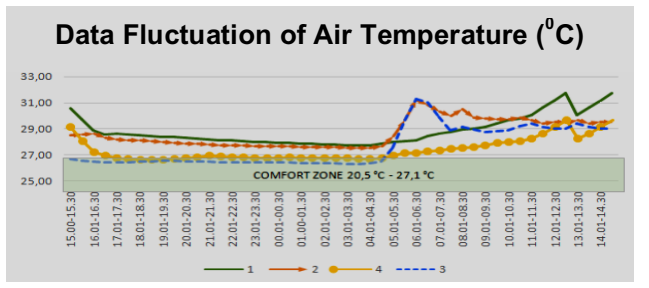

b. Aryaduta Hotel

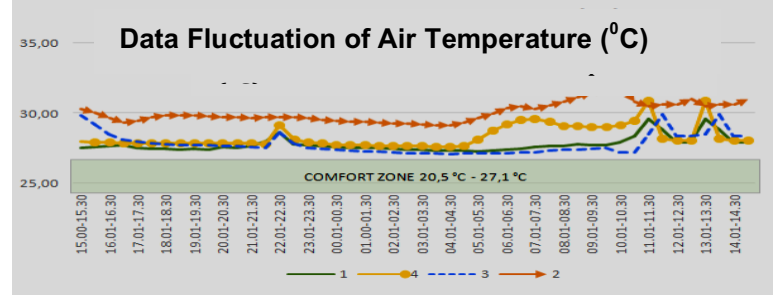

c. Sahid Jaya Hotel

Furthermore, the air temperature in Swiss-Belhotel room at 09.00 on three objectives observation was in the range of $29.83^{\circ} \mathrm{C}$ to $35.23^{\circ} \mathrm{C}$, decreased at 12.00 ranging from $29.58^{\circ} \mathrm{C}$ 
to $34.22{ }^{\circ} \mathrm{C}$, and by late afternoon at $15: 00$ it also decreased with temperatures ranging from $29.71{ }^{\circ} \mathrm{C}$ to $32.53^{\circ} \mathrm{C}$. Aston hotel room at 09.00 on three observation objectives is ranging from $25.31{ }^{\circ} \mathrm{C}$ to $29.50{ }^{\circ} \mathrm{C}$, increased at 12.00 ranging from $28.33^{\circ} \mathrm{C}$ to $30.88^{\circ} \mathrm{C}$, and by late afternoon at $15: 00$ still increasing with temperatures ranging from $28.34{ }^{\circ} \mathrm{C}$ to $31.17{ }^{\circ} \mathrm{C}$. The two international standard hotels with observations on the three objectives show a comfort zone of $20.5^{\circ} \mathrm{C}-27.1{ }^{\circ} \mathrm{C}$. More clearly the graph shows the data fluctuations in air temperature as follows:

Figure 8.Data Fluctuations of Indoor Air Temperature for Swiss-Belhotel and Aston Hotels

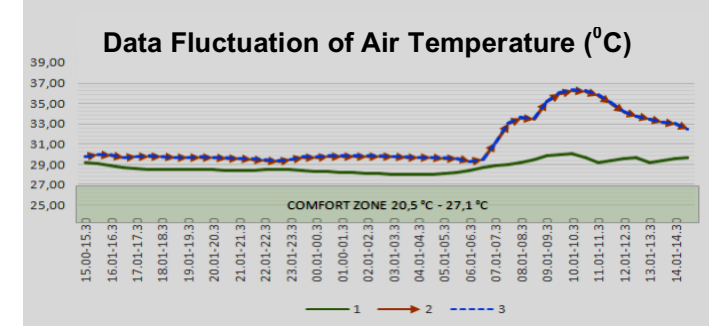

d. Swiss-Belhotel

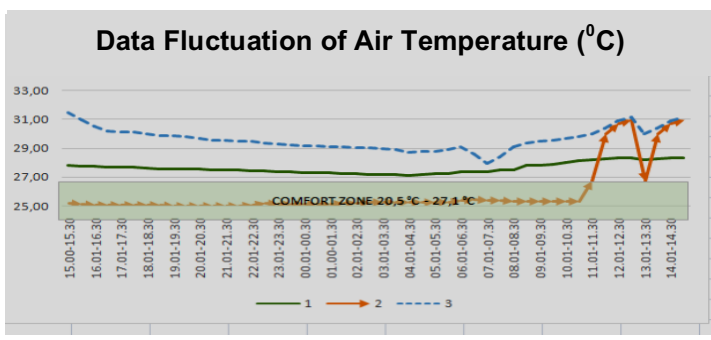

e. Aston hotel

\section{Solar Radiation Hotel Buildings}

It is known that outdoor solar radiation conditions of international standard hotel rooms are based on observation times for Grand Clarion, Aryaduta, Sahid Jaya, Swiss-Belhotel and Aston hotels with 30 objective observations data according to average, standard deviation, maximum and minimum. More clearly the table shows the conditions of outdoor solar radiation in the international standard hotel rooms.

Table 8.0utdoor Solar Radiation Conditions of International Standard Room

\begin{tabular}{lcccccc}
\hline \multirow{2}{*}{ Hotel } & \multirow{2}{*}{$\begin{array}{c}\text { Time } \\
\text { (Hours) }\end{array}$} & \multicolumn{5}{c}{$\begin{array}{c}\text { Objective Observations of Solar Radiation } \\
\text { In Outdoor Room }\end{array}$} \\
\cline { 3 - 7 } & & average & STDV & Data & Max & Min \\
\hline \multirow{2}{*}{ Grand Clarion } & 9.00 & 29.07 & 0.01 & 30 & 29,10 & 29,05 \\
Hotel & 12.00 & 39.34 & 4,41 & 30 & 46,90 & 33,10 \\
& 15.00 & 29.96 & 1,43 & 30 & 33,10 & 28,10 \\
\hline \multirow{2}{*}{ Aryaduta Hotel } & 9.00 & 54,33 & 36,38 & 30 & 128,10 & 21,90 \\
& 12.00 & 39,34 & 4,41 & 30 & 46,90 & 33,10 \\
& 15.00 & 29,96 & 1,43 & 30 & 33,10 & 28,10 \\
\hline \multirow{3}{*}{ Sahid Jaya Hotel } & 9.00 & 759,66 & 377,17 & 30 & 1113, & 153,10 \\
& 12.00 & 690,46 & 268,77 & 30 & 10 & 118,10 \\
& 15.00 & 411,96 & 210,36 & 30 & 954,40 & 99,40 \\
Swissbell Hotel & & & & & 689,40 & \\
\hline & 12.00 & 380,33 & 190,79 & 30 & 730,60 & 180,60 \\
& 15.00 & 248,50 & 34,82 & 30 & 314,40 & 181,90 \\
\hline \multirow{2}{*}{ Astonyyyyyy Hotel } & 9.00 & 1020,24 & 59,36 & 30 & 1146,90 & 960,60 \\
& 12.00 & 697,13 & 29,68 & 30 & 740,60 & 644,40 \\
& 15.00 & 591,88 & 28,43 & 30 & 644,40 & 541,90 \\
\hline
\end{tabular}

Outdoor Solar radiation of Grand Clarion hotel room at 09.00 was in an average 29.07 with a standard deviation of 0.01 with a maximum of 29.10 and a minimum of 29.05, at 12.00 it increased with an average of 39.34 with a standard deviation of 4.41 with a maximum of 46.90 and a minimum of 33.10, and late afternoon at 15.00 it decreased with an average of 29.96 with a standard deviation of 1.43 with a maximum of 33.10 and a minimum of 28.10. The regression equation for solar radiation the Grand Clarion hotel room is: $\mathrm{Y}=0.111 \mathrm{x} 2-4.874 \mathrm{x}+$ 
51.69 with the acquisition of the determinant coefficient of $\mathrm{R}^{2}=0.332$ (Figure 11a). Outdoor Solar radiation of Aryaduta hotel room at 09.00 was in an average of 54.33 with a standard deviation of 36.38 with a maximum of 128.10 and a minimum of 21.90 , at 12.00 it decreased by an average of 39.34 with a standard deviation of 4.41 with a maximum of 46.90 and a minimum of 33.10, and late afternoon at 15:00 decreased by an average of 29.96 with a standard deviation of 1.43 with a maximum of 33.10 and a minimum of 28.10 .

The regression equation of outdoor solar radiation of Aryaduta hotel room is: $\mathrm{Y}=0.111 \mathrm{x} 2$ $4.809 x+51.11$ with the acquisition of the determinant coefficient of $R^{2}=0.329$ (Figure $11 b$ ). For outdoor solar radiation of Sahid Jaya hotel rooms at 09.00 was in an averages of 759.66 with a standard deviation of 377.17 with a maximum of 1113.10 and a minimum of 153.10 , at 12.00 declining with an average of 690.46 with a standard deviation of 268.77 with a maximum of 954.40 and a minimum of 118.10 , and late afternoon at 15.00 still decreasing with an average of 411.96 with a standard deviation of 210.36 with a maximum of 689.40 and a minimum of 99.40. The regression equation of solar radiation in Sahid Jaya hotel room is: $\mathrm{Y}=$ 0.566 xs2 - 6.951x - 3.544 with the acquisition of a determinant coefficient of $\mathrm{R}^{2}=0.750$ (Figure 11c). More details can be seen in the graph of fluctuations in solar radiation data from the three hotels as follows:

\section{Figure11.Regression value for Data Fluctuation of Solar Radiation in Grand Clarion, Aryaduta and Sahid Jaya Hotel}

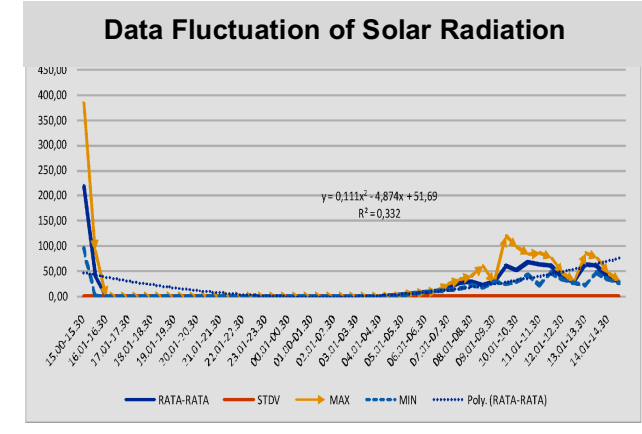

a. Grand Clarion

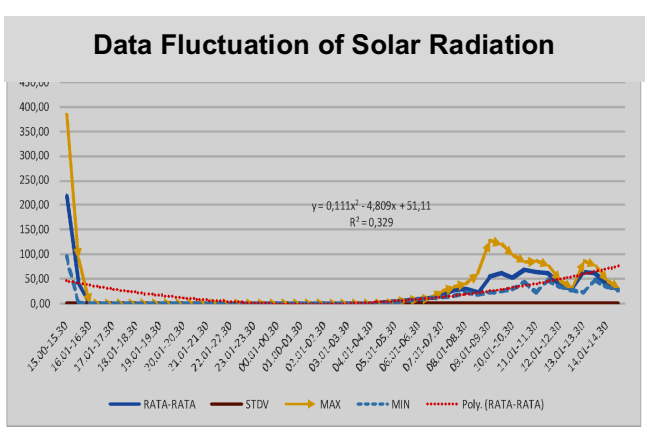

b. Aryaduta

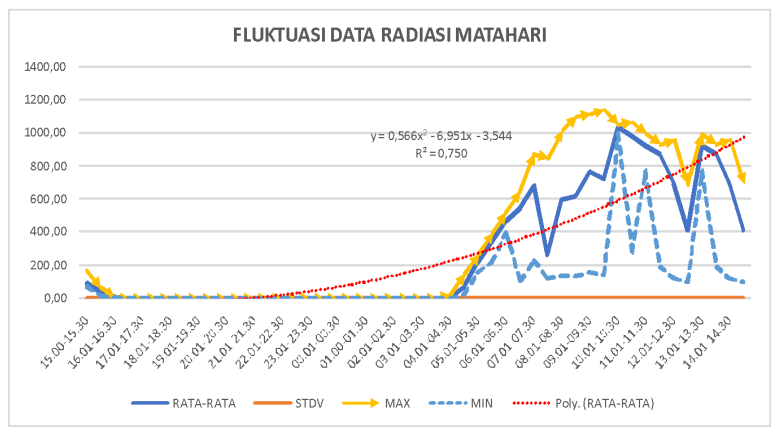

c. Sahid Jaya

Furthermore, outdoor solar radiation of Swiss-Belhotel room at 09.00 was in an averages of 146.17 with a standard deviation of 16.43 with a maximum of 174.40 and a minimum of 120.60 , at 12.00 increasing with an average of 380.33 with a standard deviation of 190.79 with a maximum of 730.60 and a minimum of 180.60, and at15:00 still decreasing with an average of 248.50 with a standard deviation of 34.82 with a maximum of 314.40 and a minimum of 181.90. The regression equation of solar radiation of Swiss-Belhotel room is: $Y=0.473 \times 2$ $13.51 \mathrm{x}+65.75$ with the acquisition of a determinant coefficient of $\mathrm{R}^{2}=0.727$ (Figure 12a). While outdoor solar radiation of Aston hotel rooms at 9:00 increased, which is an average of 1020.24 with a standard deviation of 59.36 with a maximum of 1146.90 and a minimum of 
$960.60,12.00$ decreasing with an average of 697.13 with a standard deviation of 29.68 with a maximum of 740.60 and a minimum of 644.40 , and in late afternoon at 15.00 still declined with an average of 591.88 with a standard deviation of 28.43 with a maximum of 644.40 and a minimum of 541.90. The regression equation of solar radiation Aston hotel room is: $\mathrm{Y}=$ $0.602 x 2-7.585 x-7.166$ with the acquisition of the determinant coefficient $R^{2}=0.731$ (Figure $12 \mathrm{~b})$.

Figure 12.Regression value for Data Fluctuation of Solar Radiation in Swiss-Belhotel and Aston

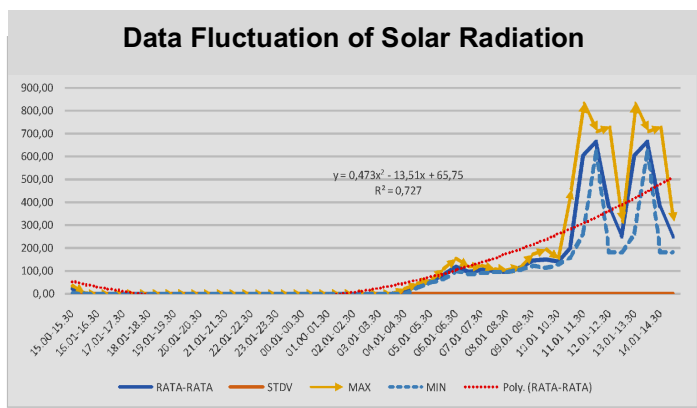

a. Swiss-Belhotel Hotel

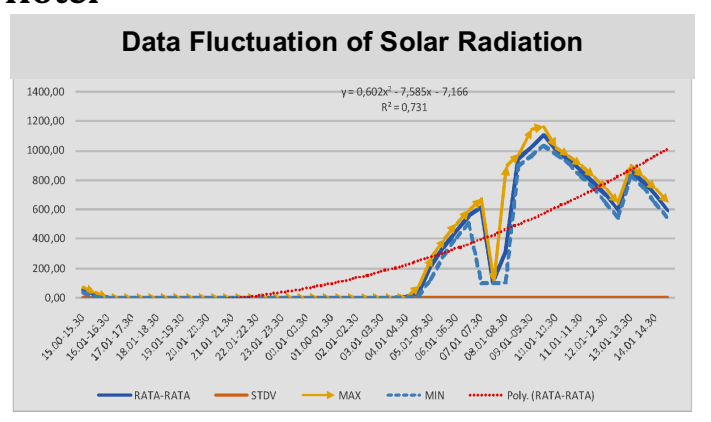

b. Aston Hotel

\section{Guests Responses toward Thermal Environment}

Guest responses to the thermal environment of the five international standard hotels were observed based on the questionnaire questions corresponding to the ASHRAE standard 55 identifying hotel guests' responses to the thermal environment in the form of air temperature, comfort feeling, preference and level of reception with hotel room air temperature.

\section{Figure 13. Respondent responses for air temperature of International standard hotel room}

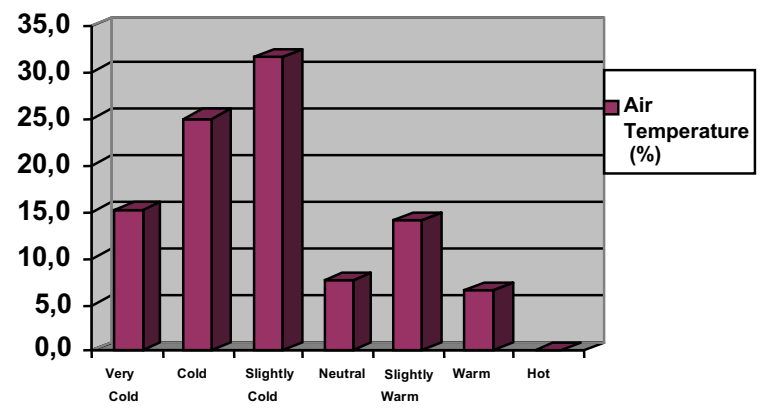

a. Air Temperature

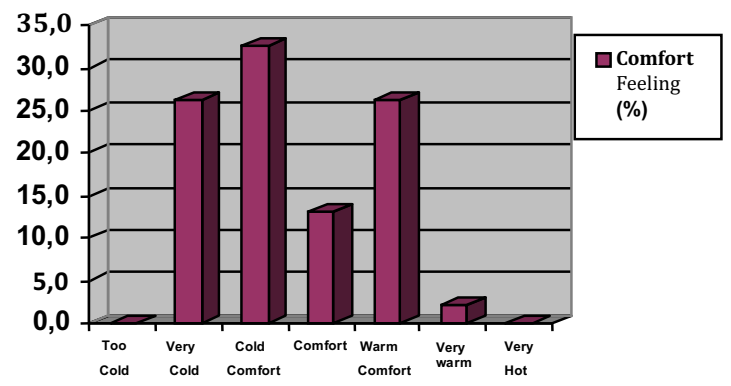

b. Comfort feeling for air temperature

The picture above shows that the respondent's response to the air temperature of the five international standard hotels observed showed that the most responds with the assumption that the hotel room is slightly cold $(-1)$ as much as $31.5 \%$ and warm (2) as much as $6.5 \%$. Means generally hotel guests want a hotel room that is slightly cold and not too warm (-1 to 2) (figure 13a). The feeling of being a guest of the five international standard hotels observed gave a response to feelings indicating a preference for cold comfort $(-1)$ of $32.6 \%$ and very warm response (2) as much as $2.2 \%$ (figure 13b). This means that respondents desire the cold comfort to very warm air temperature ( -1 to2). 
Figure 14. Respondent responses for comfort feeling and acceptance level of air temperature in International standard hotel room

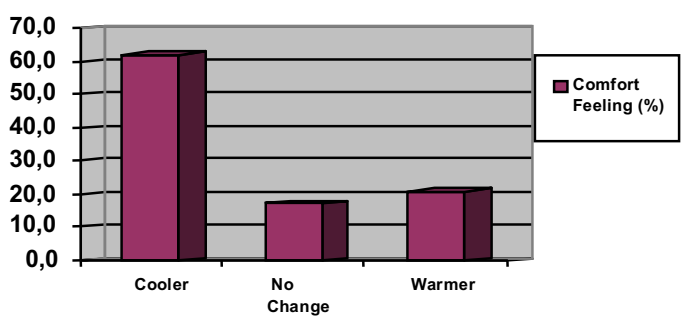

a. Comfort feeling for air temperature

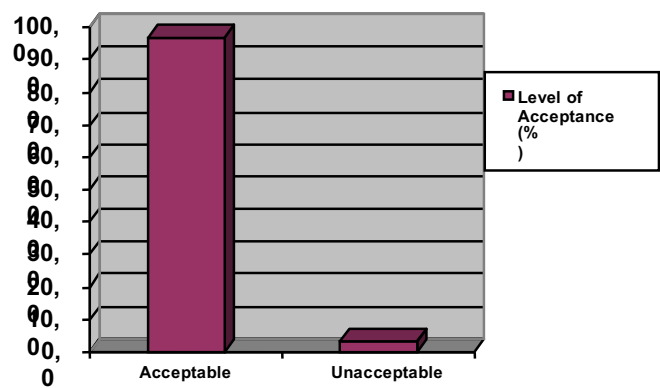

b. Acceptance level for air temperature

The picture above shows that the respondent's response to the air temperature of the five international standard hotels observed showed that the most responds to feeling like the cooler in the hotel room $(-1)$ as much as $62 \%$ and the least states there is no change $(0)$ as much $17.4 \%$. This means that generally hotel guests like coolers in hotel rooms that give a cold feeling (figure 14a). Furthermore, the level of reception for air temperatures in hotel rooms generally provides an acceptable response (1). This means that hotel guests can accept the existence of hotel rooms with air conditioning (figure 14b).

\section{Guest Response to Air Velocity}

Guest responses to air velocity at the five international standard hotels observed based on appropriate questionnaire questions of ASHRAE standard 55 identified responses based on air velocity and preferences with air velocity.

Figure 15.Respondent Response Regarding Air velocity and Preference with Air Velocity in International Standard Hotel Rooms

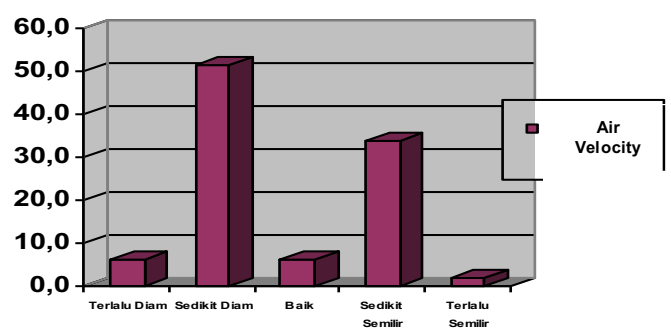

a. Air velocity

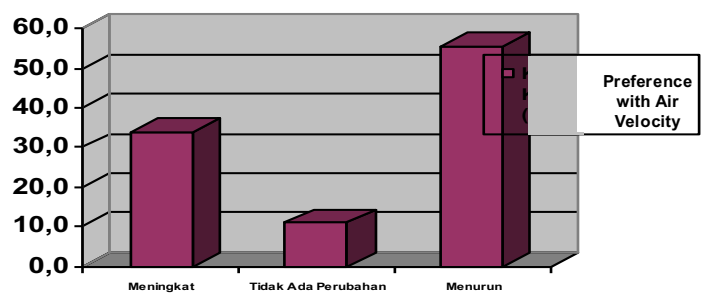

b. Preference with air velocity

The picture above shows that the respondent's response to air velocity in the five international standard hotels observed showed that the most responding to air velocity in a hotel room stated slightly silent $\quad(-1)$ as much as $51.1 \%$ and the least stated was too breezy (2) as much as $2.2 \%$. This means that generally hotel guests prefer the slightly silent to breezy air velocity in the hotel room (Figure 15a). Furthermore, guests' responses to the preference for air velocity in the hotel rooms generally prefer a decreased air speed (1) as much as $55.4 \%$ and the least stated there are no changes $(0)$. This means, guests want a decrease in air velocity in the room of the hotel room they occupy (figure 15b).

\section{Respondent Response toward Solar Radiation}

Guests' responses to indoor and outdoor solar radiation at the five international standard hotel rooms observed based on questionnaire questions that were in accordance with ASHRAE standard 55. 
Figure 16.Respondents' Response to Solar Radiation in Indoor of International Standard Hotel Rooms

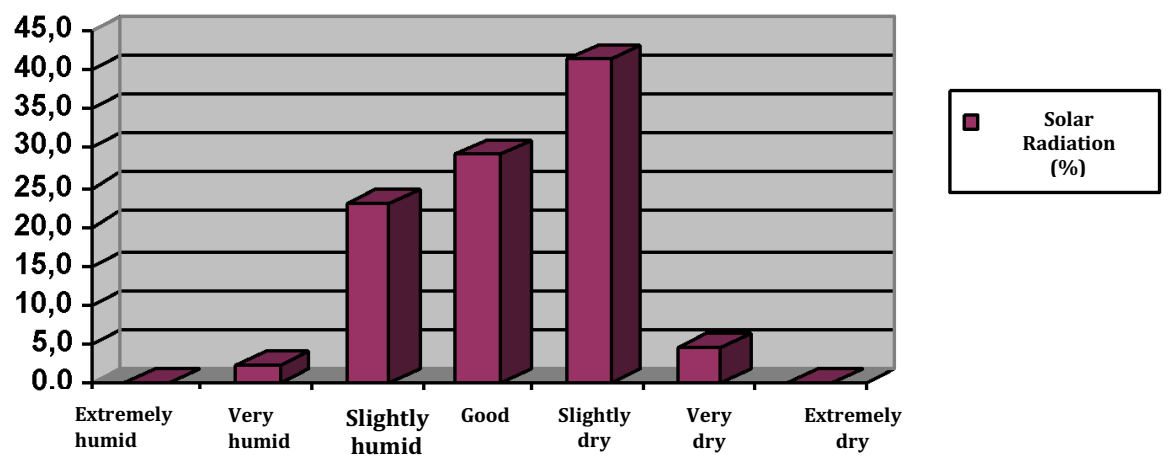

The picture above shows that respondents responses to solar radiation for indoor the international standard hotel room observed showed that the ones that gave the least dry response (1) were $41.3 \%$ and the least were very humid (-2) which was $2.2 \%$. Means generally the solar radiation indoor the hotel room started from a slightly humid to slightly dry (figure 16).

\section{Conclusion}

\section{CONCLUSION AND DISCUSSION}

Measurement and calculation of objective observations based on the orientation of air temperature of international standard hotel rooms both analyzed from indoor and outdoor have fulfilled the prerequisites of ASHRAE, thermal environmental conditions for human occupancy (Standard 55-66).Indoor air temperature of the five hotels observed at temperatures between $28.85^{\circ} \mathrm{C}$ to $29.54{ }^{\circ} \mathrm{C}$, which indicated that the hotel management always pay attention to air temperature according to indoor thermal comfort, based on the response of hotel guests who expect comfort, feeling joy and accept with the air temperature approaching the comfort zone ranges from $20.5^{\circ} \mathrm{C}$ to $27.1^{\circ} \mathrm{C}$.

The outdoor air temperature of international standard hotel room observed was in an averages ranging from $28.42{ }^{\circ} \mathrm{C}$ to $40.52{ }^{\circ} \mathrm{C}$, with a standard deviation ranging from 0.01 to 0.44 . The maximum value is between $28.45^{\circ} \mathrm{C}$ to $41.41{ }^{\circ} \mathrm{C}$ and a minimum value of $28.40{ }^{\circ} \mathrm{C}$ to $39.87{ }^{\circ} \mathrm{C}$. Indicating that the outdoor air temperature of the hotel room is high because the observations were carried out in the dry season at the three time observation treatments, namely 09.00, 12.00 and 15.00. Where the outdoor air temperature is affected by air velocity. The response of hotel guests generally comfort with silent air velocity and a decrease in air velocity that affects thermal conditions while inside the hotel room.

Solar radiation in the building of international standard hotel room observed is in an average range between 32.79 watts $/ \mathrm{m}^{2}$ to 769.75 watts $/ \mathrm{m}^{2}$, with a standard deviation ranging from 0.95 to 285.43 . The maximum value is between 36.37 watts $/ \mathrm{m}^{2}$ to 918.97 watts $/ \mathrm{m}^{2}$ and the minimum value is between 30.08 watts $/ \mathrm{m}^{2}$ to 715.63 watts $/ \mathrm{m}^{2}$. This means that solar radiation in hotel building space is extremely influences changes in indoor thermal comfort temperature in hotel rooms.

Recommendations for international standard hotel management to pay attention to the importance of indoor, outdoor, and solar radiation by considering green space, the utilization of heat-resistant materials, refusing heat absorption in buildings and reducing conventional energy use in a room treatment of hotel rooms. 


\section{Discussion}

Survey studies on international standard hotels based on the indoor thermal comfort analysis of hotel room are influenced by air orientation temperatures of the buildings. Survey of processed data, showed that from five hotels observed there were differences in the objective observations of hotel room air temperature based on the observation time at $09.00,12.00$ and 15.00. Judging from the three treatment times for Grand Clarion hotel room air temperature in the range of $29.46{ }^{\circ} \mathrm{C}$, Aryaduta ranges from $29.54{ }^{\circ} \mathrm{C}$, Sahid Jaya Hotel ranges from $28.85{ }^{\circ} \mathrm{C}$, Swiss-Belhotel ranges from $32.56^{\circ} \mathrm{C}$ and Aston ranges from $29.23^{\circ} \mathrm{C}$. This shows the difference in air temperature due to the layout of the hotel building, so the ideal temperature from the five hotels is Sahid Jaya hotel which has stability in air temperature which is between $28.76{ }^{\circ} \mathrm{C}$ to $28.95^{\circ} \mathrm{C}$.

Compared with several studies on building space, indoor air temperatures have a range of 28.2 ${ }^{\circ} \mathrm{C}$ to $33.6{ }^{\circ} \mathrm{C}$ with an average of $30.8^{\circ} \mathrm{C}$ [20]. The five international standard hotels seen from temperature data fluctuations have comfort zones ranging from $20.5{ }^{\circ} \mathrm{C}$ to $27.1{ }^{\circ} \mathrm{C}$ located in one zone in Makassar City region. This indicates naturally that hotel buildings in Southeast Asia tropics are the ideal air temperature during the dry season throughout the day, ideally the air temperature is in that range.

Observation survey study to analyze the outdoor air temperature of international standard hotel rooms, the results of comparison of the five hotels is known the average outdoor temperatures according to objective observation time treatment, namely 09.00, 12.00 and 15:00 for the Grand Clarion was at $30.92^{\circ} \mathrm{C}$, standard deviation 0.30 , maximum $31.51{ }^{\circ} \mathrm{C}$ and minimum $30.46{ }^{\circ} \mathrm{C}$, for Aryaduta is $40.52{ }^{\circ} \mathrm{C}$, standard deviation 0.44 , maximum $41.41{ }^{\circ} \mathrm{C}$ and minimum $39.87{ }^{\circ} \mathrm{C}$, Sahid Jaya is $28.42{ }^{\circ} \mathrm{C}$, standard deviation 0.01 , maximum $28.45{ }^{\circ} \mathrm{C}$ and minimum $28.40{ }^{\circ} \mathrm{C}$, for Swiss-Belhotel is $31.54{ }^{\circ} \mathrm{C}$, standard deviation 0.29 , maximum $31.98{ }^{\circ} \mathrm{C}$ and minimum $31.01^{\circ} \mathrm{C}$, and for Aston is $30.82{ }^{\circ} \mathrm{C}$, standard deviation 0.28 , maximum $31.33^{\circ} \mathrm{C}$ and minimum $30.37^{\circ} \mathrm{C}$.

The study of objective observation survey data for outdoor air temperature obtained the determinant coefficient of $\mathrm{R}^{2}$ from the regression analysis at each of the different hotels, namely for Grand Clarion $\mathrm{R}^{2}=0.620$, Aryaduta $\mathrm{R}^{2}=0.734$, Sahid Jaya $\mathrm{R}^{2}=0.286$, Swiss-Belhotel $\mathrm{R}^{2}=$ 718 and Aston $\mathrm{R}^{2}=0.428$. These results indicate that the Aryaduta hotel spread distribution of outdoor air temperature has an effect of $73.4 \%$ compared to Swiss-Belhotel $71.8 \%$, the Grand Clarion $62 \%$, Aston $42.8 \%$ and Sahid Jaya is $28.6 \%$ in influencing the condition of indoor rooms. The greater the influence of outdoor air temperature that surrounds the hotel building, the greater the effect on the effect of temperature to decrease to low temperature (cold to hot). Compared with some research results in the tropics, outdoor temperatures play an important role in changing the temperature of the building's room. In general the outdoor temperature is in the range of $28.2{ }^{\circ} \mathrm{C}-33.6^{\circ} \mathrm{C}$, which is almost the same as the air temperature (Alwetaishi, 2016). It means determining the outdoor temperature to be the main comparison to find out how much effective influence in determining indoor temperature conditions in the room, especially in changing cold conditions to cool and cool conditions to heat.

Observation survey study to see solar radiation in international standard hotel rooms indoor the results of comparison of the five hotels is known to be an average according to objective observation time treatment, namely $09.00,12: 00$ and 14.00 for the Clarion Grand 32.79 watts $/ \mathrm{m}^{2}$, standard deviation 1.95 , maximum 36.37 watts $/ \mathrm{m}^{2}$ minimum 30.08 watts $/ \mathrm{m}^{2}$, for Aryaduta at 41.21 watts $/ \mathrm{m}^{2}$, standard deviation of 14.07 , maximum 69.37 watts $/ \mathrm{m}^{2}$ and minimum 27.70 watts $/ \mathrm{m}^{2}$, Sahid Jaya at 620.69 watt $/ \mathrm{m}^{2}$, standard deviation 285.43 , maximum 918.97 watt $/ \mathrm{m}^{2}$ and minimum 123.53 watt $/ \mathrm{m}^{2}$, for Swiss-Belhotel is 258.33 watts $/ \mathrm{m}^{2}$, 
standard deviation is 80.68 , maximum is 406.47 watts $/ \mathrm{m}^{2}$ and minimum is 161.03 watts $/ \mathrm{m}^{2}$, and for Aston is 769.75 watts $/ \mathrm{m}^{2}$, standard deviation is 39.16 , maximum is $843.97 \mathrm{watt} / \mathrm{m}^{2}$ and minimum is 715.63 watts $/ \mathrm{m}^{2}$.

Objective observational survey data for solar radiation in international standard hotel room spaces obtained determinant coefficient of $\mathrm{R}^{2}$ from the regression analysis at each of the different hotels, namely for Grand Clarion $R^{2}=0.332$, Aryaduta $R^{2}=0.329$, Sahid Jaya $R^{2}=$ 0.750 , Swiss-Belhotel $\mathrm{R}^{2}=727$ and Aston $\mathrm{R}^{2}=0.731$.

Some research results can be compared, especially for tropics with high solar radiation during the dry season, where solar radiation that illuminates hotel buildings significantly affects the indoor air temperature of hotel buildings, especially inside rooms, showing solar radiation plays an important role in the occurrence changes in building room temperature $[10,20]$. It means that solar radiation greatly affects the orientation temperature according to the position of the solar radiation in the morning, afternoon and evening, so that the radiation effect is felt in the afternoon because the building material stores heat.

For the objective observations carried out on five international standard hotels of treatment, measurement and calculation of air temperature indoor rooms, and solar radiation, the respondents' responses generally showed that had the most responses to slightly cold air temperatures (-1) and the least stated warm (2) or in other words the respondent needs air from -1 to 2 . The response to feeling comfortable with the air temperature that is felt most is cold comfort ( -1$)$ and the least stated very warm (2). Means the desired response to hotel room air temperature that fosters comfort feeling of that is cold comfort conditions to very warm $(-1$ towards 2).

The response of guests to feeling comfort of the temperature in an international standard hotel room provides the most response by expressing their love for the presence of air conditioners. Respondent responses stated comfort with the air temperature in the room. The most responses said very cool $(-1)$, which responds to say there was little change $(0)$. It means that the respondent desire the cold and stable (no change) or from cold to stable air temperature in the hotel room (-1 to 0$)$. The response to the level of acceptance of air temperatures in hotels is generally acceptable (1) and unacceptable (0). Means the room temperature of all five international standard hotels is generally acceptable.

The air velocity in an international standard hotel room has the most response, the air velocity is slightly silent $(-1)$ and the least is breezy (2). This shows the respondent desire the air velocity to be quiet until too breezy ( -1 to] 2). The favorite response with the most air velocity is the decreased air velocity (1) and the least response is no change (0). Preference with the desired air velocity is that air decreases and does not change ( 1 towards 0 ).

The most response in indoor and outdoor solar radiation of hotel rooms was slightly dry (1) and the least response was very humid (-2). Means the response of hotel guests desire the condition of the rooms occupied is in very humid conditions to slightly dry, so that the room's thermal conditions are maintained (-2 towards 1$)$. 


\section{References}

Bohdanowicz, P., \& Martinac, I. M. (2002). Thermal Comfort and Energy Saving in the Hotel Industry. AMS 15th Conference on Biometeorology and Aerobiology \& 16th International Congress on Biometeorology, 28 October-1 November, Kansas City, USA.

ANSI/ASHRAE. (2017). Standard 55: 2017, Thermal Environmental Conditions for Human Occupancy. ASHRAE, Atlanta.

ISO. (2005). ISO 7730-Moderate thermal environments - Determination of the PMV and PPD indices and specification of the conditions for thermal comfort. Geneva: International Organization for Standardization.

Gagge, A. P., Stolwijk, J. A. J., \& Hardy, J. D. (1967). Comfort and thermal sensations and associated physiological responses at various ambient temperatures. Environmental research, 1(1), 1-20.

Fanger, P. O. (1970). Thermal comfort. Analysis and applications in environmental engineering. Thermal comfort. Analysis and applications in environmental engineering.

Alfano, F. R. D. A., Olesen, B. W., \& Palella, B. I. (2017). Povl Ole Fanger's impact ten years later. Energy and Buildings, 152, 243-249.

Lala, B. (2017). Analysis of Thermal Comfort Study in India. International Conference on Civil, Architecture, Environment and Waste Management (CAEWM-17)

Fabbri, K. (2015). A brief history of thermal comfort: from effective temperature to adaptive thermal comfort. In Indoor Thermal Comfort Perception (pp. 7-23). Springer, Cham.

Santoso, E. I. (2012). Kenyamanan Termal Indoor pada Bangunan di Daerah Beriklim Tropis Lembab. The Indonesian Green Technology Journal, 1(1), 13-19.

Kyriaki, E., Drosou, V., \& Papadopoulos, A. M. (2015). Solar thermal systems for low energy hotel buildings: state of the art, perspectives and challenges. Energy Procedia, 78, 1968-1973.

Ma, L., Gao, Z., Wang, Y., Sun, Y., Zhao, J., \& Feng, N. (2017). Numerical Simulation of Soil Thermal Response Test with Thermal-dissipation Corrected Model. Energy Procedia, 143, 512-518.

Kim, J. H., Min, Y. K., \& Kim, B. (2013). Is the PMV index an indicator of human thermal comfort sensation. International Journal of Smart Home, 7(1), 27-34.

O'HEGARTY, R., Kinnane, O., \& McCormack, S. (2015). Efficiency analysis of flat plate collectors for buidling façade integration. In Proceedings of International Conference CISBAT 2015 Future Buildings and Districts Sustainability from Nano to Urban Scale (No. CONF, pp. 735-740). LESO-PB, EPFL

Hendrarto, T., Sulastio, O., \& Afrinaldi, D. (2012). Kajian Proporsi Ruang-Dalam Bangunan Baru Hotel Concordia Bandung. REKA KARSA, Jurusan Arsitektur Itenas No. 1, Vol. I, Juli 1(1).

Pynkiawati, T., Wahadamaputera, S., Adiwibowo, F., Lestari, R. R., \& Septaningsih, D. P. (2009). Kajian Desain Sirkulasi Ruang Dalam sebagai Sarana Evakuasi Kebakaran pada Bangunan Hotel Carrcadin Bandung. Jurnal Itenas Rekayasa, 13(4).

Rupp, R. F., Vásquez, N. G., \& Lamberts, R. (2015). A review of human thermal comfort in the built environment. Energy and Buildings, 105, 178-205.

Tharziansyah, M., \& Rahman, A. (2008). Analisis Tingkat Kenyamanan Thermal Webb Di Rumah Tinggal T-45 Pada Musim Kemarau. Infoteknik, 9(1), 36-42.

Gandhi, P., Paritosh, K., Pareek, N., Mathur, S., Lizasoain, J., Gronauer, A., ... \& Vivekanand, V. (2018). Multicriteria Decision Model and Thermal Pretreatment of Hotel Food Waste for Robust Output to Biogas: Case Study from City of Jaipur, India. BioMed research international, 2018. https://doi.org/10.1155/2018/9416249.

ANSI/ASHRAE. (2013). Standard 55: 2013, Thermal Environmental Conditions for Human Occupancy. ASHRAE, Atlanta.

Hamzah, B., Gou, Z., Mulyadi, R., \& Amin, S. (2018). Thermal Comfort Analyses of Secondary School Students in the Tropics. Buildings, 8(4), 56

BSN. SNI 03-6572-2001. (2001). Tata Cara Perancangan Sistem Ventilasi dan Pengkondisian Udara pada Bangunan Gedung. Jakarta: Standar Nasional Indonesia.

Auliciems, A., \& Szokolay, S. V. (2007). Thermal comfort. PLEA. Notes: Note 3 Thermal Comfort; PLEA: Passive and Low Energy Architecture International in association with Department of Architecture, The University of Queensland: Brisbane, Australia 
Zhang, Z., Ma, C., \& Zhu, R. (2018). Thermal and Energy Management Based on Bimodal Airflow-Temperature Sensing and Reinforcement Learning. Energies, 11(10), 2575. https://doi:10.3390/en11102575

Alwetaishi, M. (2016). Impact of building function on thermal comfort: A review paper. Am. J. Eng. Appl. Sci, 9, 928-945.

Kosonen, R., Saarinen, P., Koskela, H., \& Hole, A. (2010). Impact of heat load location and strength on air flow pattern with a passive chilled beam system. Energy and Buildings, 42(1), 34-42.

Jaffal, I., Ouldboukhitine, S. E., \& Belarbi, R. (2012). A comprehensive study of the impact of green roofs on building energy performance. Renewable energy, 43, 157-164

Kuchen, E. (2016). Variable Thermal Comfort Index for Indoor Work Space in Office Buildings: A Study in Germany. Open Journal of Civil Engineering, 6(04), 670.

Nicol, F. (2004). Adaptive thermal comfort standards in the hot-humid tropics. Energy and buildings, 36(7), 628637. 